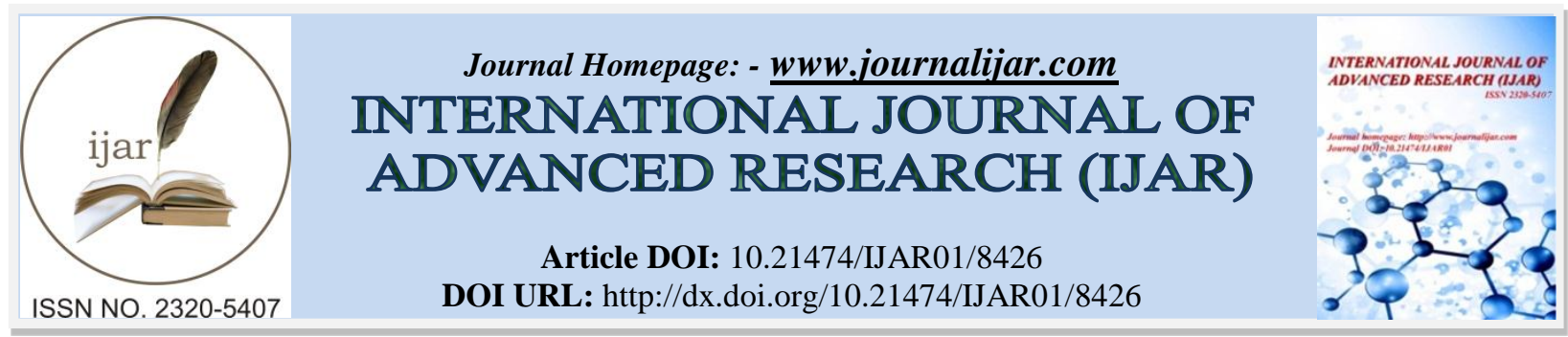

RESEARCH ARTICLE

\title{
"THE ACTIVE ROLE OF MONETARY POLICY AND FISCAL POLICY UNDER THE DOMINION OF GLOBAL ECONOMIC"(ESPECIAL SIGHT TO IRAQI ECONOMY).
}

\author{
Basheer A. Hamad.
}

Dijlah University College.

\section{Manuscript Info}

\section{Manuscript History}

Received: 16 November 2018

Final Accepted: 18 December 2018

Published: January 2019

\section{Abstract}

The present of monetary policy and fiscal policy is very necessary although the Monetarists School stresses in the importance of monetary policy more than the fiscal policy. The fiscal policy is unrealistic to effect in economic activity and it depends on the political and social effect._Although these economic justifications, the allocation function to economic resources are not solved especially that about social goods and distribution they cannot prepare without fiscal policy. The fiscal policy through expenditure government and tax policy minimize the gap between social classes in addition to the above tools; fiscal policy is used as a tool to stabilize the prices especially the basic prices of the goods. From these determents above the research problem is following ((the monetary policy cannot omit the fiscal policy role and the monetary policy loosed its efficacy because absent of real sector (real goods and sector) that subsides the price stabilization policy which is the basic target to central banks is the world. When we search in depth of monetary policy activity and fiscal policy activity and the conflict of monetary with fiscal policy and the agreement of monetary policy and fiscal policy in sometimes, the research reach to a major recommendations as followings:

1.Activating the instrument of fiscal policy tools at the local and international level in economic recession countries in order to overcome the problem of economic recession because the world live international economic exchange stage.

2. Find international monetary programs through international monetary fund to reduce the economic fluctuation that plaguing the global economy as a result of fluctuation of American economy.

3. Activation of quantitative and qualitative tools of the Iraqi central bank rather than on the exchange rate tool

4. Fiscal and monetary policy ensures the coordination of central bank in dependency instead of dependency on fiscal policy and its unrational expenditure.

Corresponding Author:-Basheer A. Hamad.

Address:-Dijlah University College. 


\section{Introduction:-}

The topic of the active role of the monetary and fiscal policies is one of the old and modern subjects, whose plays role in the power and the concentration of the government has been clearly manifested in the global recession of the 1930s and increased attention after the frequent crises of the twentieth century and the twenty-first century. The two policies are controversy among the world economist because the economic experiences are different and the strength of different economies needs to be more foresight before giving the final judgments to evaluate the two policies. Based on the above, the researcher presented the various secrets to evaluate the two policies and roles and shed light on the monetary and fiscal policies in iraq over the past century and the current century.

\section{Methodology:-}

The research was based on a methodology that included the following:

1. The problem of research: The contradiction between monetary policy and fiscal policy is often a reality, which plays on the effectiveness of economic activity throughout the world and in the Iraqi economy particularly.

2. The hypothesis of research: provided that there is often contradiction between the tools official policy and monetary policy, also in most of the economies worldwide and in Iraq in particularly.

3. The aim of the research is to explain the role of monetary policy and fiscal policy in the global economy and in the economy and the reflection of their economic effects on economic activity.

4. Research Method: The research uses the inductive and deductive approach to achieve the objectives of the research.

\section{First: Economic activity and volatility}

Economic activity according to economic theory is regulated by a market mechanism that corrects imbalances. As a rule, classics call the term "a self-regulating economy" because this economy under classical theory corrects itself to achieve long-term growth. According to the classical view the economy self- adjust to deviation from its long- term growth trend. The correction is done through a market mechanism based on flexible prices and flexible wages (schiller, 146). This analysis failed after the major global crisis of 1930. The keynesian revolution came into being. Keynesians broke the balance of classical theory after the great depression. The great depression effectively destroyed the credibility of classical economic theory. Where keynes referred to the instability of economic activity (inherent instability), while the classics pointed out and emphasized the stability of the economic activity of the economic sector as a result of the instability between economic activity emerged the role of competing monetary policy and their support, despite the difference of economic ideological schools with the keynesian school, especially the new quantity school, which emphasizes the need to stabilize the growth rate of supply at rates not exceeding $5 \%$ per year. The role of the government and through the fiscal policy appeared and represented the following:

1. Allocation function.

2. Distribution function.

3. Stabilization function.

The allocation function relates to the role of government in providing goods whose net social benefits differ from net private benefits and the government may be able to provide these goods more efficiently than the private sector. The distribution function relates to the distribution of income and wealth. The stability function is related to the use of the budget policy to achieve full employment, price stability and an appropriate rate of economic growth and balance of payments balance (Abdujman 517) Tahir, 4). In the above, three concepts of unified budget and balancing of national income and high employment budget have emerged. The budget is the official budget of the government, while the balance of national income accounts revenues and expenditures of the government according to their impact in national income accounts, and the high labor budget is an estimate of the balance of national income accounting should be at the highest level of resource use.

\section{Second: Monetary policy and fiscal policy from the perspective of the policy of the national economic stability}

The debate among economists has become acute about the possibility of monetary policy and fiscal policy in achieving economic stability (Merzlyakov, 201) The Monetarists believe that monetary policy has become the cornerstone of economic stability policy(stabilizing policy) through the keys that it has Fiscal policy with two keys has a superior advantage over fiscal policy (opcit, 274).

1. Speed and Flexibility. 


\section{Ability to retire from political pressure (solation from polit).}

When comparing monetary policy with fiscal policy, fiscal policy requires the recall and approval of parliament. This requires in practice a time delay for a certain period of time to apply fiscal policy, while the central bank can buy and sell bonds daily. At the same time, the central bank can provide the exchange rate through the interest rate often intermittently (al mostimmed) and in addition to that necessary For long-term safe economic policy. Although fiscal policy through government spending affects resource allocation and can affect taxation and political ramifadion, monetary policy is more rational than fiscal policy. Studies in the United States have shown that monetary policy more effective than fiscal policy in influencing economic activity, it influences and generates movements in consumption, investment, and aggregated output (Bruce, 1).

\section{Third: The long-term struggle between fiscal policy and monetary policy}

Keynesian economists often argue that increased government spending is the only way to provide unemployment benefits and reduce economic damage to the labor force in society; although government spending competes with Investment spending on economic resources (sulivan.622) that will be tight in the long run. In general, economic activity shifts from short to long term, and to understand the distinction between long and short term, this requiredmentioning the following points when increasing the overall production at the stage of full use of the wage and price increases. Changes in prices occur when the economy is on its way to full use and therefore price changes push the economy to a full-fledged level (summers 236). If the economy works below full employment level, wages and prices will fall and demand for money will fall, leading to a lower interest rate. The lower interest rate will stimulate investment and lead the economy to full utilization. Despite the divergence between the two policies, both fiscal and monetary policies focus on full utilization and price stability through the total demand level option (Schiller, 330). Fiscal and monetary seek to attain full employment and price stability by altering the level of aggregate demand. Their success depends on responses that are reflected in prices and on common market decisions that pertain to production. Their success depends on microecomic responses as reflect in the price and output decisions of market participant. The difference is still presented between the School of Supply Economics and the Marginal Tax rate school, which is rejected by the owners of the School of Supply Economics because they believe that high taxes are not conducive to increased employment and investment high tax rate discouraging extra work. Savings and reduction of marginal tax rates will harness the overall supply in the right direction. And practical observations to use the measure of elasticity of the tax offer which represents the overall supply response to tax rates proved to be weak in the short term (Schiller opcit, 330). These observations confirm the classic view of the polarization of fiscal policy and monetary policy, as classic economists agree that money plays an important role in determining aggregated demand, but fiscal policy is less influential in determining demand (fried, 267). This is in line with the modern view of money as asset or money for the amount of personal wealth. Wealth is a form of money but its exchange is less rapid than money for goods and services, although wealth can be goods and services (Miller 368). Money is an asset. Something of value is for part of personal wealth. Wealth in from money be exchange later for other assets goods and services. That is, money can be delayed and turned into a demand for goods because it is a form of wealth that can be held for speculative, reserve and other money functions. Finally, the impact of the interaction between monetary policy and fiscal policy will remain overall in light of the government's relationship with the Central Bank and the extent to which it gives the Central Bank autonomy.

\section{Fourthly: The importance of monetary policy the importance of monetary policy.}

Colnder believes that monetary policy is not a major goal for the US Federal Reserve in the macro economy, but it is likely that it is the largest macroeconomic policy used to achieve macroeconomic policy objectives. To illustrate this, we are reviewing some of the world's largest central banks' tests. They are probably the most used policy in macroeconomic.

\section{The U.S Federal Reserve:}

The US Federal Reserve directs and controls monetary policy, while fiscal policy is directed by the government (Colander, 114), but the two policies are ultimately directly related to the fluctuations in economic activity and in a more efficient manner, The fed induces and controls monetary policy whereas fiscal policy is induced directly by the government. It should be noted that most countries are different from the United States in terms of institutional arrangements, in which the central bank is part of the central bank, and generally the US central bank is always working to consolidate economic growth through Maintain a low inflation rate and offer cash (bernanke.p). Finally, monetary policy is viewed in a more specific way through the institutional structure of the banking system and the institutional role of the Federal Reserve in the banking system (role of the fed in that instructure structure). 


\section{The experience of the People's Bank of China:}

The Chinese Bank was founded in 1948, specifically after the victory of communism and the founding of the People's Republic of China, in 1980 changed the bank's commercial objectives to the bank. The people led to the creation of the so-called Indepent Bank State- owned. The People's Bank of China (PBOC) has begun to focus on the central bank's monetary policy objectives and the financial sector, noting that the bank has restructured the banking system according to the model provided by the US Federal Reserve, and has opened branches in the regions by focusing on the story The deployment of foreign reserves (Colander opct 115).

\section{The European Central Bank:}

In the late 1990s a number of European countries established a monetary union system, a credit system called the Euro-Credingacommon Currency, and a new central bank called the European Central Bank and its abbreviation Ecb. And then its structure in 2005, and the number of European countries that have a mechanism of 21 countries 6 permanent members (permonen member and 15 member states alternating or non-rotating members).The main objective of the ECB is mainly to maintain price stability as the central bank has been. Bunderbank is a model for the ECB and some economists are the ECB's broad model for BUNDER BANK. Most economists have taken a position towards this bank called hold waiting and see attitude. They have indicated that the ECB is a new bank and will take time to complete its programs to become a stable bank. They agreed on one view that it expects to face policy The cash represented by the difference or variation of the countries that affect the Bank's decisions in favor of these countries. It should be noted that price stability has not been achieved over the last decade and that the euro exchange rate stability has not been achieved despite all the ECB's attempts because of the balance of payments situation in these countries (Surnach, 16).

\section{Bank of England experience:}

This bank sometimes calls the Old Lady Bank on THE OLD LADY OF THREAD NEEDLE STREET. Due to the location of this bank on that street, Needless bank can be called a bank with low reserves compared to banks in the United States. The Bank (Needless) monitors the money supply through the other track, which is called to monitor cooking tea (tea control) through the open market (with equivolen of open market operation). While the British bank has a number of large banks (old lady) passes through a simple word is the word tea (tea word) and the direction of which is believed that the money supply would be going for the purpose of trading, so the money supply is managed in Britain in several ways.

\section{The Bank of Japan's experience:}

Like the People's Bank of China, the Bank of Japan is somewhat similar to the US Federal Reserve. It mainly uses the open market to monitor cash supply and cash reserve requirements, as well as the U.S Federal Reserve's actions, but allowed the banks long periods to act on their liquidity. The Bank of Japan has a number of banks. As in the U.S, banks maintain liquidity and increase their cash reserves in the United States. Japan's financial system appears to be more interdependent between the central bank, commercial banks and industrial banks than the U.S financial system. Japanese companies are funded by the Bank of Japan. Japanese commercial banks have no confidence in the Bank of Japan's work, and the Japanese central bank is in the process of restructuring loan, restructuring without causing a crack in the financial system.

\section{Fifthly. Financial Policy}

Financial policy is often defined as the use of government spending and taxes to achieve certain economic objectives. Financial policy can be defined as the use of money supply to achieve certain economic objectives. If monetary authorities wish to increase demand for high levels of income and employment, they do so by increasing supply and if you want to reduce aggregated demand, it leads to a reduction in this supply. On the other hand, government purchases as a component of the aggregate demand exert an influence on the balanced level of income. On the other hand, taxes affect the balanced level of income. If they reduce the increase in disposable income, consumption increases and total demand increases, depending on the type of tax that has been reduced and the flexibility of demand. The increase in the nominal supply of money also indirectly affects the equilibrium level of income. If the supply of money (nominal money) increases with the price level constant (pianlto, 21-22), the money supply at its real value increases on the assumption that prices are stable and as a result, investment is part of the total demand, the level of equilibrium income will increase and thus fiscal policy has been affected indirectly in the level of income equilibrium by influencing the interest rate. 


\section{The activities of fiscal and monetary policy}

The effectiveness of monetary and fiscal policy is measured on the basis of its ability to generate change in the equilibrium level. Accordingly, the greater the adherence to the equilibrium level of national income, the greater the nominal supply (monetary policy) and the change in government spending and taxation, the more effective monetary policy is determinants of the effectiveness of monetary and monetary policy do not change the relative effectiveness of these policies strongly. For example, the greater the marginal tendency for consumption, the greater the effectiveness of both fiscal policy and monetary policy. Monetary policy operates through interest and investment. For a particular change in investment, the change in equilibrium income is greater the higher the marginal inclination of consumption, the more likely a change in government procurement will lead to greater change whenever the marginal inclination is For consumption, and that the elasticity of demand for money in relation to the interest rate determines the ability of the two politicians to influence economic activity. US economic experts stress the role of economic projects (the real sector) and their cooperation in achieving fiscal policy objectives and maintaining price stability to support monetary policy to meet the challenges of balance of payments (BERNANKE, $6)$.

\section{Seventh: Interaction of monetary policy and fiscal policy in Iraq.}

The monetary policy worked through decades of the establishment of the Iraqi state and the establishment of the Central Bank to stabilize the specific value of the Iraqi dinar against the U.S dollar and foreign currencies was through this policy wants to maintain a level of general level of prices and reasonable purchasing power of the Iraqi dinar to put the Iraqi dinar a place in front of And the interest rate was set by the monetary policy at a lower level in line with the low cost of investment in the sector for decades from the twenties to the end of the eighties and the beginning of 2003. In general, the real agricultural sector met the country's domestic needs to a certain extent in some products and exported until 1973. The industrial sector also produces specific products from the food industry and some manufacturing industries that meet the local needs of the country. Thus, the real sector is supportive of the monetary sector and monetary policy is interacting with fiscal policy and in some cases harmonious, due to the commitment of the economic and political system with the constraints of the specific resources of foreign currency and the pressures of monetary policy on monetary policy. When oil was nationalized and oil revenues increased, the differences between monetary policy, fiscal policy and fiscal policy pressure began to affect monetary policy (Abdel Latif, 28). This period represents an expansion of both the monetary and financial policies, where government spending increased in all types of investment and consumption and increased employment in the state departments. The state departments began to absorb surplus labor in cities and rural areas and the impact of this absorption in the role of the agricultural sector in the national product. The rise in government spending is due to the intensification of the Arab-Israeli conflict and the increase in tension in relations with countriesNeighboring Iraq until the war with neighboring Iran 1980 and in the period 1973-1980 decreased the value of the Iraqi dinar and rose the general level of prices and inflation seemed to draw on the purchasing power of the dinar and although the Iraqi Bank was following the fixed exchange rate in exchange for, but government spending and change the structure of the industrial sectors And agriculture has its features in the demand for imports, in addition to the relative improvement in the level of income due to increased oil revenues and thus increase the level of national income in Iraq and the Gulf countries in general (Hussein, 3).

\section{The period after the Iraq -}

Iran war: The Iran - Iraq war produced an economic situation that Iraq was not envied after the war was put to the end, the government had debts that burdened the Iraqi economy and reflected on the level of economic activity. The first measures was to reduce government spending and the demobilization of part of the surplus employees On the need and the issuance of a new law that includes import without external conversion of the most productive and consumer goods, which led to an increase in the cost of importing goods and services, and consequently a reflection on the rise in costs on the general level of prices. When Iraq entered the Iran-Iraq war, fiscal policy led monetary policy by virtue of the state's tendency towards military spending (and in favor of oil revenues) and the focus on the industries that support the battle. These industries were called military manufacturing,In addition to imports, the tools of the battle of weapons and military equipment, and the addition of the import of equipment of clothing and military number associated with the protection of the soldier in the battle.In this period, the quantitative and qualitative means that were used by monetary policies, especially the means of controlling the exchange rate, were undermined due to the deterioration in the value of the dinar due to the increasing deficit in the balance of payments and the erosion of the value of the Iraqi dinar. And the decline in the role of the agricultural sector, industrial and tourism in the contribution of income and the requests of foreign workers in Iraq on foreign currency one of the 
reasons for the decline in the value of the Iraqi dinar. The Central Bank remained a policy of the state, which meets the requirements of military spending and compensation requirements of foreign workers operating and transfers from hard currency abroad. The role of banks in economic activity is a specific role because of the sovereignty of the slogan of financing the battle and meet requirements. It also paid foreign workers' remittances by transferring currency to foreign banks through the Central Bank. The Central Bank's transfers of foreign currency to meet labor payments amounted to $\$ 4$ billion in 1984, Black market conversions so that the price of the Iraqi dinar against the dollar at the end of 1981 to a dollar against dinars, while the official price was \$ 3.3 against the Iraqi dinar. It should be noted that the central bank throughout the seventies and eighties works through the tool to control the external transfer and interest rate instrument, which was characterized by relative stability due to the political system introduced a centrally directed economic system.

\section{First Gulf War:}

In the beginning of August 1990, Iraq entered a new war with Kuwait and thirty-three countries. The United Nations imposed an economic blockade that has lost the state export outlets and lost the largest source of funding for the budget. The decline in the value of the Iraqi dinar was seen as a result of the weakness of the local production apparatus for all sectors and its reliance on primitive methods of production. The fiscal policy was a burden on monetary policy and the expansion of the money supply came to meet the needs of the fiscal policy and the pressures of the state following the centralized system. At a fixed interest rate by the government and a specific exchange rate and loans that grant the government to the agricultural and industrial sector at low interest rates in comparison to the high level of national income and the real interest rate (which represents the real return on investment), Although the amount of low yield as if Measures with oil revenue. And the continuation of the import law without external transfer, and the government began to find outlets to meet its expenses, including the adoption of the new method of monetary issuance(seigniorage) to meet its expenses, which placed a burden on state employees because they receive a specific income and this burden is the monetary inflation, which absorbed the purchasing power of low-income, The second method adopted by the government is to control the farmers' product and force them to hand over the product to the government by coercive methods. The government provided a source of financing for its expenses through the receipt of the farmers' product and benefiting from the difference in the price of the payer and the sale price. In particular, some products were exported abroad, especially rice (amber), wheat and barley.(saleh,150), The third method is the use of the central bank's monopolistic power to manipulate the exchange rate to reduce it from time to time to acquire foreign currency assets for citizens, in particular the acquisition of foreign workers' remittances to their families in Iraq (Hamad, 58). The role of fiscal policy was to find outlets to generate revenues through the force of the mandatory government, as well as the monetary policy of the Central Bank to implement the requirements of fiscal policy and the use of cash issuance as a tool to achieve government spending and the situation continued until the beginning of 2003, where the invasion of US forces to Iraq.

The role of the monetary and financial policies after the U.S occupation of Iraq in 2003:

The fiscal policy after 2003 was expanded by virtue of the exit of Iraq from the embargo and under the imposition of Iraq to the law and launched oil exports and increased oil revenues to cover government spending profiteering was the focus on the return of some government facilities burned and re-employment number Of the employees under the law of the return of dismissed politicians and was the focus on consumer spending without focusing on the rehabilitation of industry and agriculture and add to government spending there are consumer spending is to meet the requirements of U.S forces, which exceeded 150 This spending was pressing for the import of goods and services to meet the needs of this military tractor. The law exempted foreign imports from taxes and the law exempting foreign investment from taxes, which led to the collapse of the remaining infrastructure of the industry and the collapse of agricultural production due to the high cost of production compared to the prices of imported products from neighboring countries. Neighboring countries opened doors to export to Iraq to improve the balance of payments (Shabibi, 13). The oil revenues contributed to excessive government spending resulting from the preparation of exaggerated budgets due to poor oversight and weakness of the government apparatus and the government's preoccupation with the security aspect and the excessive preparation of imaginary budgets, to rehabilitate the security services in the Ministry of Defense and the Ministry of Interior and add the creation of security institutions and security structures of no value such as the National Security Institute and other institutions introduced after 2003. The Ministry of Electricity has not been able to provide electric power to fill $15 \%$ of the need for domestic consumption, noting that the electricity sector spent 28 billion dollars for the period 2004-2014 according to reports of integrity, and That the oil sector could not provide the need for domestic consumption of fuel and oil and provided some products thatwere imported oil derivatives abroad and offered on the market supported 
until 2016. In general, fiscal policy has been uncoordinated with monetary policy by the dominance of political ideology, which tends to over-disregard the long-term constraints of economic resources based on corruption. In addition to this, the security situation, which is subject to breakthroughs and bombings, adds considerable expenditure to spending by necessity to compensate the martyrs and their restore and restore government institutions that are exposed to terrorist bombings.

\section{Eighth: Monetary policy after 2003}

Monetary policy followed a method that focused on exchange rate control through a managed exchange rate policy, which was used in the absence and weakness of the real sector (excluding the oil sector). The central bank reduced the exchange rate of the Iraqi dinar against the dinar and was able to reduce based on foreign currency assets and was able to reduce the value of the dollar by $40 \%$ over the period of thirteen years, from 2000 dinars to the dollar to 1200 and this force of the dinar was characterized by fluctuation, especially in times of crisis The global economy and the times of decline in the price of a barrel of oil This tool was an attempt by the Central Bank through its monetary policy to maintain the purchasing power of the Iraqi dinar and maintain a general level of prices through this tool and the tool was used as an interest rate tool to strengthen the price of The central bank raised the interest rate between 2003 and 2015 from $8 \%$ to $20 \%$ in order to absorb surplus Liquidity and reduce consumer demand, but raise the cost of investment in the safe areas and this monetary policy, the central bank has dealt a blow to the real sector in addition to the directed strikes (Hamad, 200), and the security situation has failed these assumptions used by monetary policy because the security situation, And increased the price of fuel and the cost of transportation of goods and services, and the work of the Central Bank for ten years to apply its policy independently based on the new Iraqi constitution issued after 2003, which provides for the independence of the Central Bank of Iraq. The banks have taken advantage of the opportunity to increase the interest rate, shifting most of their deposits to deposits in the Central Bank of Iraq to enhance the opportunity to develop investment in the sector due to the security situation, which does not allow the expansion of granting loans and in view of the existence of the highest yield in the deposit in the Central Bank of Iraq.

\section{Ninth. The executive branch contradicts with the authority of the central bank.}

At the end of 2012, there was a contradiction between the executive authority and the authority of the Central Bank, which worked to implement the independence clause of the Central Bank. This contradiction reflected inconsistency of the two financial policies characterized by excessive and exaggerated in meeting the requirements and expenditures of exaggerated budgets based on administrative corruption rampant in the body of the State and the policy of the Central Bank Which tries to maintain the purchasing power of the Iraqi dinar against the dollar through the instrument of exchange rate and interest rate instrument.

\section{Conclusions:-}

1. The role of fiscal and political policy in economic activity is determined by the strength and size of the economy at the international and domestic level.

2. The ability of monetary policy to influence economic activity depends on the size of the financial market and on the Bank's ability to use monetary instruments and qualitative instruments.

3. The impact of fiscal policy on economic activity remains effective in all economies, especially in the period of economic recession.

4. The US Federal Reserve model is the most traditional model by global central banks despite the different economic philosophy of the world.

5. The financial and monetary policy can do its volume in influencing economic activity especially in the real sector and the sector of goods and services, which has flexibility relative to energy production countries in the recovery phase.

6. The monetary policy in Iraq has affected the absorption of surplus existing liquidity in commercial banks during the period 2004-2008 by increasing the interest rate.

7. The excessive budget estimates by fiscal policy have reduced the role of monetary policy for 2004-2014.

8. The weak role of the real sector in Iraqi economic activity has defined and restricted the role of the specific instruments of monetary policy in Iraq for the period 2004-2014.

9. The rampant administrative corruption is losing the hard currency assets of the Central Bank of Iraq and thus determining the Bank's ability to use the managed exchange rate policy to control the general level of prices.

10. The central bank's ability to manage the exchange rate has been determined by the issue of oil exports and thus the policy's ability to influence economic activity has been determined. 
11. The issue of the contradiction fiscal policy and monetary policy failed the paragraph of the Constitution, which provides for the independence of the bank because of the spread of corruption in the system of implementation of annual budgets.

\section{Recommendations}

1. Engage in economic blocs due to the role of the monetary and financial policies at the international and local level.

2. Activate the role of the financial market at the local level so that quantitative and qualitative monetary policy tools and policy instruments can influence economic activity.

3. Activation of financial policy instruments at the local and international levels in times of economic recession because the world is living in the stage of globalization and international economic exchange through the International Monetary Fund.

4. Find international monetary programs through the International Monetary Fund to reduce the volatility in the economy to reduce the volatility in the world as a result of fluctuations in the US economy and reduce the impact of the policies of the Federal Reserve.

5. Find international cooperation programs to activate the role of fiscal and monetary policies in economic activity through the benefit of countries with global productive capacity, ie countries that have relative flexibility of production capacity.

6. Activation of quantitative and qualitative tools of the CBI instead of focusing on the interest rate instrument and exchange rate instrument.

7. Activate the role of rational budgets in Iraq, which is based on rational appreciation and non-waste in public money, as well as budgets that focus on investment in the agricultural sector, industrial and service and tourism, and under the standards of international investment and accounting for all those who fail to comply.

8. Find real solutions to restructure and build the agricultural sector, industrial, tourism and service to benefit from local and international experiences.

9. Define new controls to control the conversion of foreign currency to the outside world and new controls on the managed exchange rate policy.

10. Increase the Bank's ability to influence activity rather than link the proceeds of oil exports to foreign currency.

11. Coordinate fiscal policy and monetary policy in Iraq to ensure the independence of the central bank instead of subjecting the central bank and monetary policy under the dictates of fiscal policy of irrational expenditure.

\section{References:-}

1. Schiller. The economy today .Mc graw.Newyork. Eleventh edition.

2. Merzylaykov.Serger.Stratigic interaction between fiscal and monetary in an export economy. And economics.2012.special issue.

3. Schiller.Bardely.R.The economi tody.Mcgraw.Ninethedition.Newyork.

4. wonnactt.Paul and Blomovist.Ake and Joel Fried.Macroeconomic.Fourthedition.copy right .Mcgraw-hill 1994.

5. Miller.RogerLeroy.Econmic today Newyork..14 thedition.Mcgraw-hill Irwin.

6. Colander .David.Macroeconomic. newyork-Mcgraw-hill Irwin. Sixth edition.

7. Surnach.Jardi 8 Raul Ramos.Peterclay. Testing. Ftpl Across government tries.Reasrch institute of applied economics 2008.

8. Sayder. Trico Cowell and Bruce Donal. Tax cuts and interest rate cuts:an empirical comparison of effective of fiscal and monetary policy.Coxwell @wpuniedo and dbruce @utkedu.

9. Kohn.Donald.the imbalance in the U.S.A economy .conference proceding. The lery economic institute of brids college

10. Davsion,Paul.Is declining dollar good for U.S.A Economey?conferenceproceding -The lery.

11. Hale ,David.do the repulicans need trillion dollar current count deficit to keep white house in 2008.

12. J.Bradforelong 98 LawerenceH.Summers.Fiscal policy in depressed economy.Brooking paper on economic activity.spring 2012.

13. Hamd, Basheer Alwan. The role of financial institutions in motivation of economic activity in the crises of the globalized economy. Journal of Accounting Studies and Finance - Volume 4 - Number 19 for the year 2012 Higher Institute of Accounting and Finance - University of Baghdad.

14. AbdJuman, Michael. Faculty of Economics and Politics. Riyadh Dar Al - Marikh for Publishing 1999.

15. Hamd, Basheer Alwan. Delete the three zeros, Journal of Accounting Studies and Financial, Volume 5, Issue No. 10 , 2010 - Higher Institute of Accounting and Finance - University of Baghdad . 
16. ALShabibi, Sinan Features of monetary policy in Iraq. Arab Monetary Fund 2007. The Secretariat of twoGovernorates of the Central Banks and Arab Monetary Institutions.

17. Saleh, MudherMohammed: Monetary Policy of the Central Bank of Iraq and the Requirements of Stability and Economic Growth.

18. Darj, Ali Ahmed, Hussein, Wisaam. Measuring the impact of changes in crude oil prices on some of the economic indicators of the Gulf Arab countries members of the OPEC for the period (1990-2007) Al Mustansiriya Journal of studies and Arab research and International No. 39.

19. Abdl-Latif. Emad Mohamed. Goverment debt and its impact on monetary policy Al-Mustansiriya Journal of studies and arab research and international.

20. Annual Publication issued by the Central Bank of Iraq 2007. 